\title{
Portuguese and Brazilian Family Business: in Between Urgency and Delay Perceptions in the Succession Process
}

\author{
Ana Paula Marques \\ Associate Professor, PhD of Sociology (University of Minho/Portugal), Senior \\ Researcher at the Communication and Society Research Centre (CECS) \\ Leandro Alves da Silva \\ Post-doctorate at the University of Minho/Portugal
}

\section{Abstract}

Family business has been the focus of several studies over the last two decades and its relevance has been supported by the interdisciplinary perspectives in the fields of management, entrepreneurship, economics, psychology, and sociology. Despite that, there is still insufficient knowledge about the key role of family influences in the business, namely the intergenerational management succession, its planning and effectiveness. According to a recent research focused on the entrepreneurial succession in Portugal (AEP, 2011), 50\% of family businesses are not passed on to the second generation and only $20 \%$ reach the third generation. In fact, business succession planning has been identified as one of the most challenging steps in the life of the family firm, both in maintaining the competiveness of the business, and in overcoming intra/ inter family conflicts. Nonetheless, resistance to succession, relationship founder/ successor, planning of succession, and type of organisational culture, among others, explain how executive succession is one of the most important and hardest tasks in organisational life (Zahra, 2005). This paper will be supported mainly by qualitative data, taking into account the main results from the project "Roadmap for Portuguese Family Businesses" (NORTE2020/FEDER) developed in Portugal (Marques, 2018) and in Brazil (Silva, 2018), which analyses in-depth interviews conducted to Portuguese (N 23) and Brazilian (N 11) founders/managers/owners. In the present article we wish to discuss the main management challenges of a family business, particularly the importance of succession preparation and the role of the family in the socialisation of the second (third or subsequent) generation.

Keywords: Portugal, Brazil, family business, succession, socialisation 


\section{Introduction}

Family business has been the main focus of several studies over the last two decades and its relevance has been supported by the interdisciplinary perspectives in the fields of management, entrepreneurship, economics, psychology, and sociology. Despite that, there is little consensus regarding its definition (Moores, 2009; Tagiuri \& Davis, 1996) and above all there appears to be insufficient knowledge about the key role of the family influences in business, namely the intergenerational management succession, its planning and effectiveness. According to a recent research which focused on the entrepreneurial succession in Portugal (AEP, 2011), 50\% of family businesses are not passed on to the second generation and only $20 \%$ reach the third generation. Similar empirical findings were observed in the project "Roadmap for Portuguese Family Businesses" (NORTE2020/FEDER) developed in the North region of Portugal (Marques, 2018), and a set of critical aspects were pointed out, such as: i) less attention / preparation from family businesses to succession planning/ business leadership; ii) higher exigencies of balancing family, property and business; iii) vulnerability in attracting and, above all, retaining qualified professional, partly due to the "bad image" regarding the prevalence of careers and practices of nepotism or paternalism in family enterprises.

The family is one of the most reliable social structures in the transmission of values and rules through generations (Gersick et al., 1997). Family culture is part of one of three circles of family firm systems according to established literature (Moores, 2009; Tagiuri \& Davis, 1996), which explain its importance in establishing and maintaining the family firm's culture. These interactions make up the role of the family and it is expected to expand knowledge through the concepts of familiness and socioemotional wealth (Berrone et al., 2010). In fact, the socialisation of the next generation plays a key role both in the structure of the family structure and in maintaining or reinforcing business strategies in order to increase its performance and competitiveness in the internationalised markets. Therefore, business succession planning has been identified as one of the most challenging steps in the life of the family firm, both in maintaining the competiveness of the business and in overcoming intra/ inter family conflicts. However, founders and CEOs of family firms tend to be resistant to change or intentional (although not always conscious) postponement in dealing with the succession of the company (Naldi et al., 2007; Zellweger et al., 2007).

This paper will be supported mainly by qualitative data taking into account the main results from the project "Roadmap for Portuguese Family Businesses" (NORTE2020/FEDER) developed in Portugal (Marques, 2018) and in Brazil (Silva, 2018), which provides an analysis of in-depth interviews conducted to Portuguese (N 23) and Brazilian (N 11) founders/managers/owners. We aim to discuss the main management challenges of a family business, particularly the importance of 
succession preparation and the role of the family in the socialisation of the second (third or subsequent) generation.

The structure of this paper is articulated as follows: firstly, studies and theories focused on the succession process and its constraints and critical aspects are outlined; secondly, methodological notes both from the Portuguese and Brazilian contexts are presented, including research design and the sociodemographic profile of the interviewees in our study; thirdly, attention will be given to the analytical dimensions of discussion both about the succession process, and about familiness and socioemotional wealth. Lastly, we will outline research results, and present conclusions.

\section{System, relationships and family culture}

Family is a social system approved by law and practices in order to take care of the needs of its members. The bond that keeps the family together also accommodates it throughout its lifespan and the complex interpersonal relationships are constituted by the emotions and emotional ties developed there, bringing over the sense of responsibility and loyalty to the family as a system (Kepner, 1983, p. 60). In particular, the family aims to respond to emotional and social needs of its parties, namely: the feeling of belonging to a group and the individual's self-worth; the intimacy provided by the family, accompanied by the appreciation and esteem of each of its members; and the identity and development of autonomy through the differentiation of assigned social roles (associated norms and expectations).

The organisation of the family traditionally occurs in three subsystems: the couple's, the parents' and the children's. The couple aims to address the needs and expectations in the man-woman relationship and support the family system as a whole: acting in the family decisions and leading actions of symmetry, complementarity and reciprocity (Kepner, 1983: 62). When raising and educating their children, parents have a direct influence on how the conflicts between them are managed. The children are defined as an educational group to the social rules communicated by the parents. In turn, they can act as friends and/or compete for their parents' attention and approval. Hence, they experience moments with achieved expectations, while others are frustrated and with disputes for space and recognition.

Families, as well as companies, have a particular form of organisation. The main goal is to seek the unity of the family nucleus (father, mother and children) by means of "verbal rules of conduct" and "strong patterns of behavioural restriction": consciously communicated or maintained in an unconscious way. That regulation is established within the family culture. For Kepner (1983, p. 64), culture is defined as:

"[...] a way of understanding and thinking, judging, assessing and feeling; a way of acting towards the others, of doing things and solving problems. Culture deals with questions of internal integration and social survival, and consequently, it tends to be 
transmitted as a set of solutions adopted for the next generations. By providing a set of rules for action, the cultural pattern, whether adopted or inherited, is aimed at reducing anxiety; it gives direction, value and meaning to what could be experimented such as confusing and overwhelming events. Families develop rules to reinforce their culture. These are generally hidden, but can be deduced through behaviour and communication".

In this regard, family culture always expresses its members' relationships and feelings, wherefore family conflicts also integrate the cultural dimension of the family. These may be analysed as the way whereby the family system deals with the differences between its members. In other words, it may follow suppression strategies, or eventually, debilitation strategies of the means of communication and gestures of affection, enhancing the discussion and questioning of the rules and customs. In turn, the repression of the conflict which motivates disagreement does not make it disappear, since everything nearly always tends to be repressed, hidden, dormant and, in a set opportunity, may reappear more aggressively and violently, even risking the sustainability of the family ties in the medium and long term.

Nevertheless, in view of the profound transformations of the family structures along the twentieth and beginning of the twenty-first century (Torres, 2002; Leandro, 2001), new insights are required about the implications of the social and gender roles within the framework of the family relations reconfigured nowadays. A consequence of the decline of marriage, the increase of the divorce rate, the tendency for cohabitation and multiple marital arrangements, and new family ties (Wall, 2005), the family system faces relevant internal challenges concerning the attributions and contents of the roles of the respective members that integrate it, with significant impacts on the potential dimension of conflicts and complex strategies that need to be mobilised in order to mitigate or suppress them.

The self-regulating systems of implicit and explicit principles of the action, usually with a strong emotional nature, take on a crucial dimension both in intra-family and business life, and in family relations, business and society in general. They tend to configure strategies of preservation of material (a position held in the social class structure) and immaterial heritage, related with the economic resources (and property) and the investment in school credentials. Those systems also include strategies of transmission of the family ethos, its traditions and values, apart from the preservation of the "secret" of the family business and the privileged connection with the surrounding community. These aspects enable the appraisal of the "family culture" in the direction of familiness (Habbershon \& Williams, 1999), by means of the resources that the family business has in the interaction of the family as a whole. In short, specific literature revisited (Table 1) may highlight the main dimensions both of familiness and of socioemotional wealth.

Table 1 - Familiness and socioemotional wealth cultural dimensions 


\begin{tabular}{|c|c|c|}
\hline $\begin{array}{l}\text { Cultural } \\
\text { dimensions }\end{array}$ & Familiness & $\begin{array}{l}\text { Socioemotional wealth } \\
\text { (SEW) }\end{array}$ \\
\hline $\begin{array}{l}\text { Professional skills } \\
\text { of family members }\end{array}$ & $\begin{array}{l}\text { - Reputation and } \\
\text { experience } \\
\text { - Organisational (decision } \\
\text { making and learning) } \\
\text { - Process (network of } \\
\text { relationships) (Berrone et } \\
\text { al., 2010) }\end{array}$ & $\begin{array}{l}\text { - Control and the influence } \\
\text { of the family } \\
\text { - Identification of the family } \\
\text { members with the company } \\
\text { (Newbert \& Craig, 2017) }\end{array}$ \\
\hline Succession & $\begin{array}{l}\text { - Shared vision and } \\
\text { purpose, unique language, } \\
\text { stories and culture } \\
\text { - Relational: trust, norms, } \\
\text { obligations and identity } \\
\text { (Gómez-Mejía et al., 2016) }\end{array}$ & $\begin{array}{l}\text { Renovation of the family ties } \\
\text { to the business by means of } \\
\text { dynastic succession } \\
\text { (Moyano, 2007) }\end{array}$ \\
\hline $\begin{array}{l}\text { Strategic vision of } \\
\text { the business }\end{array}$ & $\begin{array}{l}\text { - Decision propositions } \\
\text { that reach property, } \\
\text { management and control } \\
\text { - Proficiency/competence } \\
\text { of the active members in } \\
\text { the family business (Barros } \\
\text { et al., 2017) }\end{array}$ & $\begin{array}{l}\text { - Control and influence of } \\
\text { the family. (Berrone et al., } \\
\text { 2012) }\end{array}$ \\
\hline $\begin{array}{l}\text { Relationships } \\
\text { between partners } \\
\text { and non-family } \\
\text { managers }\end{array}$ & $\begin{array}{l}\text { - Family bond - employed } \\
\text { - Identity of the family } \\
\text { business (Zellweger et al., } \\
\text { 2010) }\end{array}$ & $\begin{array}{l}\text { - Social bonds } \\
\text { - Emotional attachment } \\
\text { (Berrone et al., 2012) }\end{array}$ \\
\hline $\begin{array}{l}\text { Rivalry between } \\
\text { generations }\end{array}$ & $\begin{array}{l}\text { - Information sharing } \\
\text { between the active } \\
\text { members in the family } \\
\text { business } \\
\text { - Transgenerational } \\
\text { orientation (Barros et al., } \\
2017 \text { ) }\end{array}$ & $\begin{array}{l}\text { - Renovation of the family } \\
\text { ties to the business by means } \\
\text { of dynastic succession } \\
\text { (Moyano, 2007). }\end{array}$ \\
\hline
\end{tabular}

Source: Own elaboration

\section{Methodological notes}

A study developed in 2011 by consultancy Egon Zehnder International (Carniaux \& Schuler, 2011, p. 32) ${ }^{1}$ with 720 managers worldwide based on experiences in family businesses, pointed out the main causes of the conflicts which were organised in three

1 This study involved 720 managers worldwide, who were asked a set of question based on their experiences in family businesses. 
specific domains: capital, business and family. Also, the European Family Business Barometer (KPMG, 2017) foresees that in the next five years, at the European level, the greatest transfer of power and intergenerational wealth in modern times will occur. However, the issue of succession remains simultaneously one of the critical points and challenges of any family business, mainly due to the lack of preparation of the successor. In the project "Roadmap for Portuguese Family Businesses" (NORTE2020/FEDER) developed in Portugal, in order for the company to achieve success, three strategic conditions were identified, namely: the ability to separate family and business interests; the existence of strategic planning in the medium and long term; and the planning and training of the successor before the effective start of functions. In sum, these studies converge in the importance of key critical or challenging aspects in the family business, but also put emphasis on the lack of knowledge regarding the internal dynamics of a family business so as to highlight conflicts and strategies that will enable coping in the succession process. The option of a qualitative research approach is justified if we take into account the theoretical background supported in the family business culture (Gersick et al., 1997), particularly its family history, identity and motivational structures, and the familiness as a set of idiosyncratic resources based on owners' values, such as reputation, trust, enterprising spirit, local responsibility, and so on. Furthermore, in order to expand our understanding regarding this issue, the analyses of two different countries have been provided through the triangulation of in-depth interviews conducted to Portuguese (N 23) and Brazilian (N 11) founders/managers/owners.

At the beginning of the data gathering process, access to these companies was negotiated with the family leaders or owners. In each country, the researcher provided information regarding both the purpose of the study through an initial conversation, and the establishment of the interview protocol (with specificities according to the national context) ${ }^{1}$. The interview had an open-ended format and was geared towards several topics like the history of the company, business characteristics, governance strategies, internationalisation and the challenge of digital economy, profiles and employees, and other aspects of internal functioning. The respondents were invited to answer questions about their assumptions regarding those topics. Thus, for the purpose of this paper we will be focusing on their assumptions in the relation between family and firm concerning the succession process, as well as the perceived changes in the business during its history and the near future. As we mentioned previously, our main goal consists not only in highlighting how the succession process was (or not) planned, but also in focusing on the role of the family in the socialisation of the second (third or subsequent) generation.

\footnotetext{
${ }^{1}$ Each interview was audiotape-recorded and immediately transcribed verbatim by the researcher. For content analysis, MaxQDA was used for codification of the interview.
} 


\section{Main findings and discussion}

\section{Profile of founders/ family owners from Portugal and Brazil}

In Portugal, among the 23 interviewees, two-thirds are males aged between 30 and 60 (the 40 to 50 age group is the most significant), and the overwhelming majority holds higher education degrees (undergraduate, master's and doctorate). Moreover, they are either founders or $2^{\text {nd }}$ generation entrepreneurs, although some are already $3^{\text {rd }}$ generation or subsequent, who predominantly assume the status of managing partner or CEO, and have been at the head of the company's destinies for more than 20 years.

In Brazil, 11 people were interviewed, among whom 35\% were women. Two-thirds are present in the age group from 40 to 60 and the vast majority hold higher education degrees (undergraduate, master's and doctorate). The Brazilian sample included founders, $2^{\text {nd }}$ or $4^{\text {th }}$ generation entrepreneurs who predominantly assume the status of CEO and partners who have been leading the company's destinies for more than 30 years.

Broadly, the most frequent words that emerged from the interview content were, in great prominence, "company", followed by "family", "non-family member", "work", "business", "generation", and "sons and daughters".

\section{Succession challenge and family conflicts: common aspects and singularities}

In the current paper we wish to discuss the main management challenges of a family business, particularly the resistance to succession, the relationship founder/ successor, succession planning and the role of the family in the socialisation of the second, third or subsequent generations. As the number of family members increases, and in spite of the fact that more options become available for choosing the successor, there may be a greater number of family members who do not wish to work in the family business, even though they expect to derive benefits from it. On the one hand, these attitudes can generate tension within the family and among the members who work in the company versus those who do not and; on the other hand, they can exacerbate existing conflicts. Hence, it is vital to establish rules of conduct that define how the family interacts in management through the definition of governance structures with the purpose of promoting its continuity.

Three strategies may be emphasised according to our main findings: 1) postponement of the succession accompanied by the naturalisation of the "future" successor mainly in firms from the first generation; 2) informal and unplanned succession process due to the death of the founder or due to gender role bias; 3 ) recognition of the succession preparation as a way of guaranteeing the company's longevity, including potential sources of conflict, some of which are explicit and others latent. 
Bearing in mind the first strategy, the absence of established rules puts emphasis on the postponement of the formalisation of the succession process, assumed as a pacific process among the family descendants. Moreover, in some circumstances, namely in one Brazilian firm, succession seems to be programmed, although no kind of formal instrument has been used to guarantee that.

“No, I didn't [think about succession]! I have two children, and they also like this space very much. Succession will obviously be theirs, it will be theirs, but let's see how it goes in two years' time, let's wait and see!" (E4_1st Generation_Portugal)

"For now they [children] are still studying and they are still young, although the eldest already helps us at the weekend. He has been out with us to do some repair work on some machines to help us out. In fact, we wanted to give him a sense of responsibility and teach him how to earn his own money, his pocket money. Getting their own remuneration is also very enticing for them." (E20_1st Generation_Portugal)

"The power structure is maintained in the next generation: the chosen one was the eldest son of our current president. Today succession is arranged" (E3_ 2nd Generation_ Brazil).

However, the absence of established rules also places emphasis on the conflicts and continuity of the business itself. When the founder died or got ill, the lack of suitable communication between the direct or indirect descendants, as well as the specific training to manage the company, were pointed out as critical challenges to the governance strategy and the guaranteed family staff professionalisation.

"Communication between collaborator, management and company direction is distant. My uncles barely speak to each other and this has consequences on their subordinates who end up getting very few guidelines regarding what should be done. In the morning they get one directive and in the afternoon they may get a different one." (E3_1st Generation_Brazil).

"There has never been effective dialogue. After my grandfather had a heart attack and was told to stop working, we tried joint management which didn't work between the two brothers. The heads of the company were set up regardless of the powers (...) succession wasn't prepared, power wasn't transparent and the business would yield until they realised that the financing gap was huge." (E5_4th Generation_Brazil).

In this situation, according to literature on the topic (cf. Table 1), the family's socioeconomic health is affected and the capacity to renew the family ties with the company after a succession process is called into question. The emotional bonds between brothers, the assignment of duties and responsibility among the family members, managing expectations and dividends, constitute critical moments towards the maintenance of the family business: 
"My brother and I communicate differently with the employees. We speak in a different way and this is not good for me. How can I manage my emotions at work?" (E4_2nd Generation_Brazil).

"My brother centralised power after our father died, so dialogue between us decreased. (...) My other brother makes payments without my consent. This disallows me in front of my employees.". (E1_2nd Generation_Brazil).

"My cousin was placed in the company regardless of the advice proposed by the family. This has been causing some conflict when the employees do not know whose directions they should follow." (E5_4th Generation_Brazil).

In turn, the fact that social roles are assigned to the different members of the family according to gender illustrates both the persistence of cultural patterns based on sexism, and the rupture of those patterns when we project the transference of the business succession onto the daughter, due to the fact that she has higher academic qualifications and professionalisation. The latter situation is particularly emphasised in the case of family businesses analysed in Portugal.

"Succession is done by men. There is sexism in the power structure of the family business. My uncle, one of the founders, didn't explain how the partner should be respected. He was very technical and not as flexible; he would end up listening to our opinions, but today, not even this happens." (E1_2nd Generation_Brazil).

"Sexism is in the organisational culture. Capital is allocated via the persistence of sexist behaviours that were dealt with, however, they still come back and make social coexistence somewhat cumbersome." (E6_2nd Generation_Brazil).

Nevertheless, either because they are owners/shareholders, or because they hold managerial positions, family businesses undergo relevant transformations, in particular because they put emphasis on female entrepreneurs, for example in traditional sectors such as metalworking. To take up high-end positions effectively performing duties has been relevant at the level of the 2 nd and 3rd generation family companies. The choice of this "female" leadership may be rooted in the fact that the descendants are only women, but it may also happen due to these women's profile. In addition, it is important to bear in mind that many managers/owners tend to hold academic qualifications which are more suited for specific areas of the business in the Portuguese family businesses under analysis in the current paper.

"We know for a fact that women have had fewer opportunities than men! That is obvious, but I personally prefer to look at people, in other words, I prefer to know if they are good professionals, whether male or female! If they perform their duty well, his/her opportunities will become available and he/she will have his/her place (...)" (E6_4th Generation_Portugal) 
"My father said: '- My dear daughter, I was wondering if you would like to work at the factory?' I just stared at him, at the factory? 'The thing is, I don't see your sisters working there! If you don't do it, I can't see any of them adapting to that reality." (E9_5th Generation_Portugal)

"It is a very positive experience! Apart from the fact that it's a woman working in the company - and I have had proposals to work outside - I am a member of some associations precisely because I am a woman in the area of business management. Somehow that opens some doors and brings some recognition. It is good to see that people acknowledge you, and also, to see how the company has evolved in just a few years." (E1_2nd Generation_Portugal)

Lastly, the strategy set up to prepare succession starts in the definition of the formal instruments of power transfer and constitution of the administrative boards, though to a lesser extent in the companies analysed in Portugal, by comparison with the ones from Brazil. When succession happens, not exempt from conflict, its preparation is decisive, as we can observe from the testimonies below:

"In 2001, my father and my uncle realised that in order to ensure the continuity of their business they depended on us, we had to be involved, and also the capital and they also depended on the capital invested here. If they sold the business, they would never get the value they wanted, the fair price for them! Thus, they realised that if they donated it to us or gave us the opportunity to continue managing the business, they could have a fixed income, a steady income until the they died. And that's exactly what happened. There were deals, meetings and they realised that we [my sister and I] would be the followers, the next in line. That was the decision, but it was prepared by our father, taking into account our decision. We said that we needed some safeguards, we didn't want to work in the company for 10 or 20 years and at the time of our death we would be fighting each other. Let's define dates, set up when that happens. What safeguards will you give us? (...) There is a document ... part of it was donated and another part was the right of usufruct and usufruct could be claimed at any time (...). There was some conflict, as expected, and different opinions. There were moments when it seemed that this would be in vain. We went back and forth, but in the end it worked! I believe that there is merit, in this case, thanks to my father and uncle who accepted, but thanks to us as well for giving them the safeguards they wanted, ensuring they would still be connected, safe!" (E23_3rd Geração_Portugal)

"My 30year-old cousin applied for the presidency of the company. He met all the requirements formalised in the family protocol and approved by the boards: administrative, societal and familial. The only thing missing was to have his application approved by the administrative board. Two foreign advisors refused his application for deeming the candidate's professional profile immature. Two more internal/family advisors - from a total of five advisors - did the same. My cousin immediately walked away from the succession line, and today he is only a shareholder 
and lives in another country. Although he had met all the requirements for the presidency, it hadn't been specified what professional experience was necessary for the relatives to apply for succession" (E2_2nd Generation_Brazil).

"We will not accept the "put in a good word" mechanism. We plan succession and worry about the qualifications and training of the heirs. There are goals for those who apply for succession: both training and academic goals. (...) I try to deal with the second generation with care, tactfulness and a certain degree of control. Some who participate in the boards end up understanding the developments of neutrality and transparency, strengthening relationships without getting involved emotionally " (E2_2nd Generation_Brazil).

"Another family member was hired. He caused differences in the business strategies: he lacked the human competence, so the path to professionalisation was still open. A family board was created and a nephew was brought in to perform the duties aligned with the business management. There, a breach for professionalisation occurred, with the selection of an entrepreneurial manager. (...) We had to map processes and create departments for professionalisation. Now there is someone reporting to the four partners. Also, a system of managerial management was hired for the financial autonomy of the company." (E7_2nd Generation_Brasil).

"A headhunter was hired: he brought in an executive from the labour market to try and invert the company outcome. Consultants of family businesses were also hired. (...). By virtue of the very bad financial outcomes, governance tools have been used to help in the differences of personal values between the two brothers who were making decisions within the company. Those conflict scenarios were reported to partners and collaborators. A family business consultant suggested the following conditions: the two brothers ahead of the business should sign a shareholders' deal and install a family advisory board. In three months they managed to sign the shareholders' deal, however the partners saw their powers decrease and also their roles in the business operation, generating doubt among the managers as to who they should listen to. Should they abide by their rules or obey the executive director. (...) The new executive board proposed a limit of competences to the executives which was accepted by the partners. The cap intended to restrain the degree of uneasiness between their relationship. The board proposed was created with the aim of understanding how the new family members would continue in the company. It didn't work due to the level of offences, non-productive discussions, and it greatly affected people's emotional health." (E5_4th Generation_Brazil).

\section{Conclusions}

Our results point to the importance of meeting the redefinitions which emerge from the concept of family and its relationship with the family business, given the importance of the family in the socialisation dimension and in the transmission of values and norms geared towards the business, with a crucial influence on the 
continuity of the business and on the capacity to manage the resulting conflicts. It is essential then, to confer visibility to culture, power relations (e.g. conciliation, conflict), but also to the relations of complicity, respect, trust of the family members (executive and non-executive) involved in the life of family businesses and conciliation with the family.

In effect, in the comparison between Portuguese family businesses and their Brazilian counterparts, it was possible to highlight both the common aspects, and the singularities associated with the succession strategies. Right from the start, it is important to mention that the respondents acknowledged the importance of succession as a practice for the longevity of the business. The successor's and the former owner's legitimacy is transmitted through the power structure, and it is possible to communicate the deep knowledge about patrimony and the respect for the limits of wealth creation. That legitimacy is also communicated via the mission and legacy of culture transmitted to the generations, value networks and their background. However, for the first generation Portuguese companies, for example, that question is "natural" due to the family ties established, thus postponing its preparation. As for the Brazilian companies, what becomes clear is the importance of preparing succession through protocols, family councils and other tools to resolve conflicts resulting from the division of incomes, assignment of roles and responsibilities among family members, hiring or not hiring of family members and non-family members, among other aspects.

Similarly, the persistence of conflicts in the process of succession makes it urgent to rethink the internal communication mechanisms within the company and in its relationship with the family, in particular regarding the identification of problems an emotional nature. The latter assumes a particular prominence in the Brazilian companies analysed. The renewal of the family bonds with the company constitutes an important moment to reaffirm the dimensions of familiness, namely cognitive, affective (reputation, trust, loyalty, etc.), organisational (education, training and decision-making) and transgenerational to ensure the continuity of the business (communication, planning and professionalisation).

Lastly, we should highlight the importance of family reputation and resilience associated to the concern in maintaining family leadership before the external economic environment. By guaranteeing an intangible "brand", the family businesses aim to increase the means and tangible resources for the sustainability of its economic activity, becoming competitive in markets which are increasingly globalised. Simultaneously, due to the strong bond with the place where they were born, the commitment and territorial cohesion make these economic agents become relevant actors for local development. 


\section{References}

[1] AEP (Associação Empresarial de Portugal) (2011). Livro Branco da Sucessão Empresarial. AEP, Available online at: http://sucessaoempresarial.aeportugal.pt/documents/SUCESS\%C3\%83 O_Livro\%20Branco.pdf. (access on January 12, 2020).

[2] Barros, I. et al. (2017). Familiness and socioemotional wealth in Spanish family firms: An empirical examination, European Journal of Family Business, Volume 7, Issues 1-2, 14-24, ISSN 2444-877X, https://doi.org/10.1016/j.ejfb.2017.06.004.

[3] Berrone, P. et al. (2010). Socioemotional wealth and corporate responses to Familiness and socioemotional wealth in Spanish family firms institutional pressures: Do family-controlled firms pollute less? Administrative Science Quarterly, 55(1), 82-113.

[4] Berrone, P. et al. (2012). Socioemotional wealth in family firms theoretical dimensions, assessment approaches, and agenda for future research. Family Business Review, 25(3), 258-279.

[5] Carniaux, A. \& Schuler, M. (2011).Family businesses - best-in-class with minor flaws - 10th International Executive Panel, Germany, Egon Zehnder International: 32.

[6] Gersick, K., et al. (1997). Generation to Generation. Life Cycles of the Family Business. Boston, Massachusetts: Harvard Business School Press.

[7] Gómez-Mejía, L. R., et al. (2016), Capturing the Familiness of Family Businesses: Development of the Family Influence Familiness Scale (FIFS). Entrepreneurship Theory and Practice. 10.1111/etap.12229.

[8] Habbershon, T.G., Williams, M.L. (1999). A Resource-Based Framework for Assessing the Strategic Advantage of Family Firms. Family Business Review, 12 (1), 1-26.

[9] Kepner, E. (1983). The Family and The Firm: A Coevolutionary Perspective - Organizational Dynamics, Summer, 57-70.

[10] KPMG (2017). European Family Business Barometer, (Sixth Edition), Available online at: https://home.kpmg.com/xx/en/home/insights/2017/11/europeanfamily-business-barometer-confidence-in-unity-sixth-edition.html, Access on 23-05-2018.

[11] Leandro, E. (2001). Sociologia da família nas sociedades contemporâneas. Lisboa: Universidade Aberta.

[12] Marques, A. P. (2018). Empresas familiares da região Norte. Mapeamento, retratos e testemunhos. Edições Diário do Minho, (http://hdl.handle.net/1822/55802) 
[13] Moyano-Fuentes, J. (2007). Socioemotional wealth and business risks in family-controlled firms: Evidence from Spanish olive oil mills. Administrative science quarterly, 52(1), 106-137.

[14] Moores, K. (2009). Paradigms and theory building in the domain of business families. Family Business Review, 22(2), 167-180.

[15] Naldi, L., et al. (2007). Entrepreneurial orientation, risk taking, and performance in family firms. Family Business Review, 20(1), 33-47.

[16] Newbert, S. \& Craig, J. B. (2017). Moving Beyond Socioemotional Wealth: Toward a Normative Theory of Decision Making in Family Business. Family Business Review, 30(4), 339-346. https://doi.org/10.1177/0894486517733572.

[17] Silva, L. A. (2018). Estudo sobre a identificação e classificação de conflitos nas empresas familiares. 340-366. In A. P. Marques (Org.). Roadmap para empresas familiares: mapeamento, profissionalização e inovação. ISSN: 9789899676824/doi:10.201814/1822.56256.

[18] Tagiuri, R. \& Davis, J. (1996). Bivalent attributes of the family firm. Family Business Review, 9(2), 199-208.

[19] Torres, A.C. (2002). Casamento em Portugal. Uma Análise Sociológica. Oeiras: Celta Editora.

[20] Zahra, S. A. (2005). Entrepreneurial risk taking in family firms. Family Business Review, 18(1), 23-40.

[21]Zellweger, T. M et al. (2010). Exploring the concept of familiness: Introducing family firm identity. Journal of Family Business Strategy, 1(1), 54-63.

[22] Wall, K. (2005). Famílias em Portugal. Percursos, interacções, redes sociais. Lisboa: Imprensa das Ciências Sociais. 